\title{
К ВОПРОСУ ГОМОЛОГИИ В СТРУКТУРНОЙ ОРГАНИЗАЦИИ КОСТЕЙ ПРОКСИМАЛЬНЫХ СЕГМЕНТОВ КОНЕЧНОСТЕЙ ЧЕЛОВЕКА
}

\author{
(ㅇ Яшина И.Н. ${ }^{1}$, Иванов А.В. ${ }^{1}$, Клочкова С.В. ${ }^{2}$ \\ ${ }^{1}$ Курский государственный медицинский университет (КГМУ) \\ Россия, 305041, Курская область, г. Курск, ул. К. Маркса, д. 3; \\ ${ }^{2}$ Первый Московский государственный медицинский университет имени И.М. Сеченова \\ (Сеченовский Университет) \\ Россия, 125009, г. Москва, ул. Моховая, д. 11, стр. 10
}

\begin{abstract}
Цель исследования - выявление закономерностей и различий в структурной организации плечевых и бедренных костей, связанных с функциями конечностей с учетом их принадлежности к стороне тела.

Материалы и методы. Проведена остеометрия 35 анатомических структур на 308 костях проксимальных сегментов свободных конечностей людей. С целью учета влияния соматотипа человека на размеры костных структур данные были нормализованы. За единицу измерения был принят поперечный диаметр диафиза на середине длины кости. Полученные результаты были обработаны методами факторного анализа Maximum Maximum Likelihood Factor с вращением Equamax normalized, при этом были сгенерированы четыре выборки, учитывающие принадлежность к поясу конечности и стороне тела.

Результаты. Особенностями структурной организации плечевой кости явилось выделение в качестве базового структурного параметра первого уровня ширины проксимального эпифиза, для бедренной кости сагиттального диаметра головки и межвертельного расстояния. Асимметричность структурной организации костей и вертикальная дифференциация эпифизов контрлатеральных костей определены наличием нестабильных параметров. Асимметрия структурной организации бедренной кости более выражена. Нестабильных параметров проксимального эпифиза правой бедренной кости выделено 4, дистального эпифиза - 1 ; в структурной организации проксимального эпифиза левой бедренной кости выделен 1 , дистального эпифиза - 3. Нестабильных параметров проксимального эпифиза правой плечевой кости выделено 3 , дистального эпифиза - 2 ; в структурной организации эпифизов левой плечевой кости выделено по 6 нестабильных параметров.

Заключение. Основу структурной организации костей проксимальных сегментов конечностей человека независимо от принадлежности к поясам конечностей и стороне тела образуют анатомические образования, отвечающие за трансляцию силовых нагрузок по оси конечности. Функциональная дифференциация конечностей человека отражается в структурной организации костей асимметричной вертикальной дифференциации эпифизов плечевых и бедренных костей.
\end{abstract}

Ключевые слова: плечевая кость; бедренная кость; структурная организация; факторный анализ.

Яшина Ирина Николаевна - канд. мед. наук, доцент кафедры анатомии человека, КГМУ, г. Курск. ORCID iD: 0000-00016235-2309. E-mail: bik2709@rambler.ru (автор, ответственный за переписку)

Иванов Александр Викторович - д-р мед. наук, профессор, заведующий кафедрой гистологии, цитологии и эмбриологии, КГМУ, г. Курск. ORCID iD: 0000-0002-2412-0475. E-mail: anatomy@mail.ru

Клочкова Светлана Валерьевна - д-р мед. наук, профессор кафедры анатомии человека, Сеченовский Университет, г. Москва. ORCID iD: 0000-0003-2041-7607. E-mail: swetlana.chava@yandex.ru

Увеличение продолжительности жизни наряду с изменениями спектра двигательной активности современного человека, гиподинамия, ожирение, травмы, инфекционные заболевания и многие другие факторы, воздействующие на опорно-двигательный аппарат, приводят к возрастающей частоте развития дегенеративно-дистрофических заболеваний крупных суставов человека, которые существенно снижают качество жизни человека. Большинство дегенеративно-дистрофических заболеваний опорно-двигательного аппарата носят системный характер и поражают одновременно несколько суставов. При этом исследования патологии опорно-двигательного аппарата связаны с конкретными заболеваниями: поражениями тазобедренного, коленного, плечевого или локте- вого суставов. При изучении системной организации проксимального эпифиза бедренной кости при коксартрозе [10] мы столкнулись с недостатком информации о структурной организации костей здорового человека, которая необходима для понимания причин и механизмов асимметричной дезорганизации бедренных костей при развитии дегенеративно-дистрофических заболеваний. Развитие современных технологий обработки информации открывает новые возможности для анализа данных, полученных классическими анатомическими методами исследования.

Цель настоящего исследования - выявление закономерностей и различий в структурной организации плечевых и бедренных костей, свя- 
занных с функциями конечностей с учетом их принадлежности к стороне тела.

\section{МАТЕРИАЛЫ И МЕТОДЫ ИССЛЕДОВАНИЯ}

Исследование выполнено на 308 мацерированных плечевых и бедренных костях людей (77 правых плечевых, 77 левых плечевых, 77 бедренных правых и 77 бедренных левых), умерших на рубеже 20-21 веков, не несущих признаков патологии костной ткани, с полным синостозированием эпифизов.

По классической методике остеометрии производились измерения гомологичных структур плечевых и бедренных костей (в таблицах 1-3 и на рисунке 1 представлено описание структур и схемы измерения углов, характеризующих стереометрию костей) с учетом принадлежности к проксимальному эпифизу, диафизу и дистальному эпифизу.

Для измерения использовались устройство для измерений длинных трубчатых костей [2], цифровой штангенциркуль и транспортир. С целью учета влияния соматотипа человека на размеры костных структур данные, полученные в ходе остеометрии, были нормализованы. За единицу измерения был принят поперечный диаметр диафиза на середине длины кости.

Для решения поставленных задач на следующем этапе исследования применили метод факторного анализа - Maximum Likelihood Factor с вращением Equamax normalized, при этом были сгенерированы четыре выборки, учитывающие принадлежность к поясу конечности и латерализацию кости. Все требования к выборкам для проведения факторного анализа были выполнены. В качестве корреляционной матрицы использовалась матрица корреляции Спирмена. Поскольку методологически алгоритмическая схема реализации метода максимального правдоподобия включает последовательное выделение латентных факторов с объяснением наибольшей доли дисперсии исходных переменных, процесс выделения факторов был прерван на уровне отсутствия изменений в картине факторных нагрузок и их дисперсий при увеличении числа факторов. Статистически значимыми, влияющими на структуру при $\mathrm{p} \geq 0,05$, явились факторные нагрузки со значениями в диапазоне $|0,7-1,0|$.
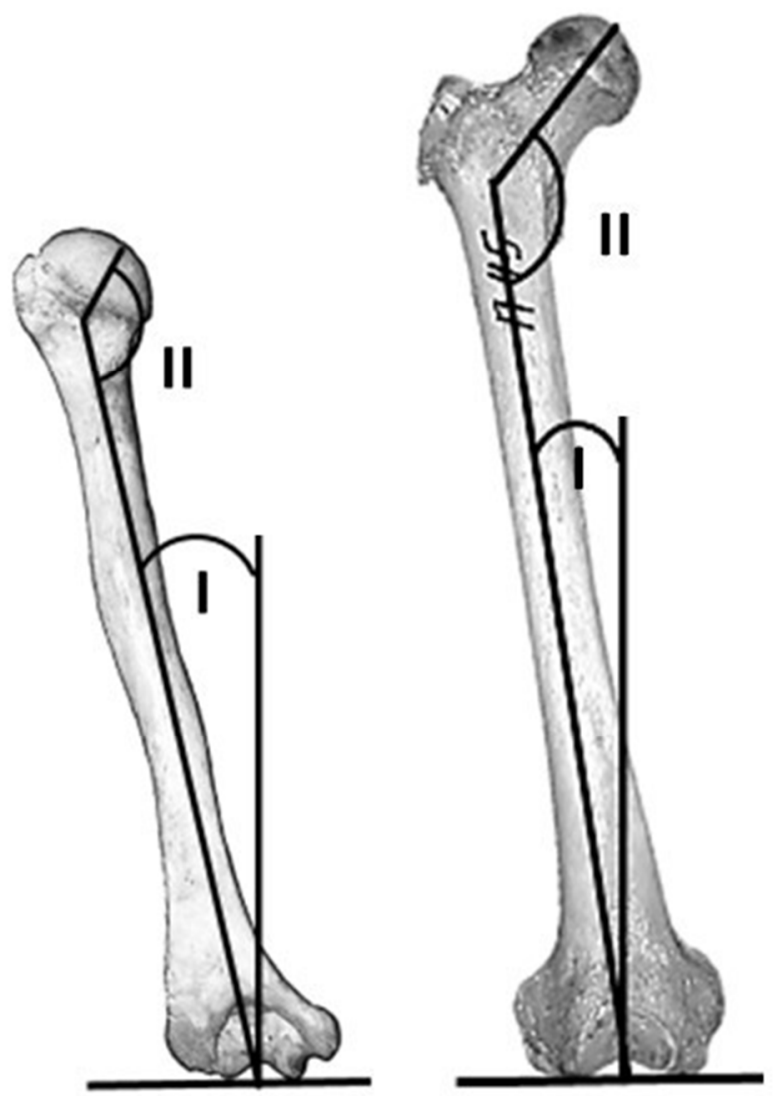

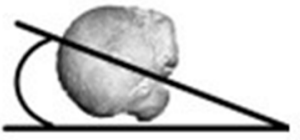

III

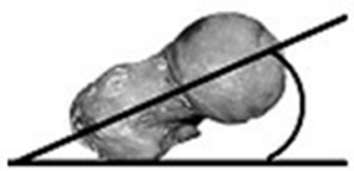

III

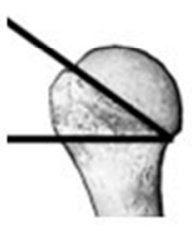

IV

Рис. 1. Схема измерения углов, характеризующих стереометрию костей.

Примечание: I - угол наклона диафиза, II - диафизарно-шеечный угол, III - угол скрученности плечевой кости / угол анте/ретроверсии шейки бедра, IV - угол хрящевого края головки плечевой кости.

Fig. 1. The scheme of measurement of angles characterizing the stereometry of bones.

Note: I - angle of the shaft axis, II- shaft-neck angle, III - angle of torsion of humerus / angle of ante-retroversion of the femoral neck, IV - angle of the cartilaginous edge of the humerus head. 
Обозначение структур проксимального эпифиза плечевых и бедренных костей человека The osteometric parameters of the proximal epiphysis structures of human humerus and femur

\begin{tabular}{|c|c|}
\hline $\begin{array}{l}\text { Homep } \\
\text { Number }\end{array}$ & $\begin{array}{c}\text { Обозначение } \\
\text { The osteometric parameters }\end{array}$ \\
\hline 1 & $\begin{array}{l}\text { Ширина проксимального эпифиза для плечевой кости - наибольшее расстояние между голов- } \\
\text { кой и большим бугром, для бедренной - наибольшее расстояние между головкой и большим } \\
\text { вертелом. } \\
\text { The width of the proximal epiphysis for the humerus is the greatest distance between the head and the major tubercle, for the } \\
\text { femur is the greatest distance between the head and the major trochanter. }\end{array}$ \\
\hline 2 & $\begin{array}{l}\text { Сагиттальный диаметр головки или передне-задний размер головки, измеренный в горизон- } \\
\text { тальной плоскости. } \\
\text { The sagittal diameter of the head or anterior-posterior head size, measured in the horizontal plane. }\end{array}$ \\
\hline 3 & $\begin{array}{l}\text { Вертикальный диаметр головки или верхне-нижний размер головки, измеренный во фрон- } \\
\text { тальной плоскости. } \\
\text { The vertical diameter of the head or top-bottom size of the head, measured in the frontal plane. }\end{array}$ \\
\hline 4 & $\begin{array}{l}\text { Сагиттальный диаметр шейки или передне-задний размер шейки, измеренный в горизонталь- } \\
\text { ной плоскости. } \\
\text { The sagittal diameter of the neck or anterior-posterior neck size, measured in the horizontal plane. }\end{array}$ \\
\hline 5 & $\begin{array}{l}\text { Вертикальный диаметр шейки. Расстояние, измеренное между максимально удаленными } \\
\text { верхней и нижней точками шейки кости. } \\
\text { The vertical diameter of the neck. The maximum distance between the upper and lower points of the bone neck. }\end{array}$ \\
\hline 6 & $\begin{array}{l}\text { Задняя длина шейки - расстояние между краем головки бедренной кости и серединой межвер- } \\
\text { тельного гребня. } \\
\text { The back neck length is the distance between the edge of the femoral head and the middle of the intertrochanteric crest. }\end{array}$ \\
\hline 7 & $\begin{array}{l}\text { Верхняя длина шейки бедренной кости - расстояние между основанием большого вертела и } \\
\text { краем головки бедренной кости сверху. } \\
\text { The upper length of the femoral neck is the distance between the base of the major trochanter and the head from above. }\end{array}$ \\
\hline 8 & $\begin{array}{l}\text { Межбугорковое расстояние - расстояние между вершинами большого и малого бугорков пле- } \\
\text { чевой кости. Межвертельное расстояние - расстояние между вершинами большого и малого } \\
\text { вертела бедренной кости. } \\
\text { The intertubercular distance is the distance between the tops of the major and minor tubercles of the humerus. The intertro- } \\
\text { chanteric distance is the distance between the peaks of major and minor trochanters. }\end{array}$ \\
\hline 9 & The width of the intertubercular groove. The internal distance between the crests of the tubercles. \\
\hline 10 & $\begin{array}{l}\text { Глубина межбугорковой борозды - расстояние между дном и касательной линией, проведен- } \\
\text { ной между гребнями бугорков. } \\
\text { The depth of the intertubercular groove is the distance between the bottom and the tangent line drawn between the crests of } \\
\text { the tubercles. }\end{array}$ \\
\hline 11 & $\begin{array}{l}\text { Диафизарно-шеечный угол. } \\
\text { The shaft-neck angle. }\end{array}$ \\
\hline 12 & $\begin{array}{l}\text { Угол скрученности кости или анте- (ретро-) версии шейки кости, угол отклонения оси шейки } \\
\text { кпереди или кзади от фронтальной плоскости, проведенной по задней поверхности мыщелков. } \\
\text { The angle of torsion of the bone or ante- (retro-) version of the bone neck, the angle of deviation of the neck axis anteriorly or } \\
\text { posteriorly from the frontal plane drawn on the back surface of the condyles. }\end{array}$ \\
\hline 13 & $\begin{array}{l}\text { Угол хрящевого края головки с диафизом (измеренный по методу В.Г. Властовского). } \\
\text { The angle of the cartilaginous edge of the neck with the shaft (measured according to V.G.Vlastovsky’s method). }\end{array}$ \\
\hline
\end{tabular}

Примечание: Серым цветом обозначены ячейки структур, характерных только для одной из костей.

Note: The gray color indicates the structures that are specific to only one of the bones. 
Обозначение структур диафиза плечевых и бедренных костей человека The osteometric parameters of shaft structures of human humerus and femur

\begin{tabular}{|c|c|}
\hline $\begin{array}{l}\text { Hoмep } \\
\text { Number }\end{array}$ & $\begin{array}{c}\text { Обозначение } \\
\text { The osteometric parameters }\end{array}$ \\
\hline 14 & $\begin{array}{l}\text { Наибольшая длина кости, измеренная между максимально удаленными точками на нижней } \\
\text { поверхности медиального мыщелка и наивысшей точкой на головке. } \\
\text { The maximum bone length measured between the most distant points on the lower surface of the medial condyle and the high- } \\
\text { est point on the head. }\end{array}$ \\
\hline 15 & $\begin{array}{l}\text { Наибольшая длина кости, измеренная между максимально удаленными точками на нижней } \\
\text { поверхности медиального мыщелка и наивысшей точкой на большом бугре или большом вер- } \\
\text { теле. } \\
\text { The maximum bone length, measured between the most distant points on the lower surface of the medial condyle and the } \\
\text { highest point on a major tubercle or major trochanter. }\end{array}$ \\
\hline 16 & $\begin{array}{l}\text { Поперечный диаметр диафиза - расстояние между боковыми точками на середине длины кости } \\
\text { во фронтальной плоскости. } \\
\text { The transverse diameter of the shaft is the distance between the side points in the middle of the bone length in the frontal } \\
\text { plane. }\end{array}$ \\
\hline 17 & $\begin{array}{l}\text { Сагиттальный диаметр диафиза - передне-заднее расстояние, измеренное на середине длины } \\
\text { кости. } \\
\text { The sagittal diameter of the shaft is the anterior-posterior distance measured in the middle of the bone length. }\end{array}$ \\
\hline 18 & $\begin{array}{l}\text { Угол наклона оси диафиза по отношению к перпендикуляру, восстановленному от горизон- } \\
\text { тальной плоскости мыщелков. } \\
\text { The angle of the axis of the shaft with respect to the perpendicular restored from the horizontal plane of the condyles. }\end{array}$ \\
\hline 19 & $\begin{array}{l}\text { Степень изогнутости диафиза или расстояние между передней поверхностью диафиза на сере- } \\
\text { дине длины кости и плоскостью, проведенной между задними поверхностями головки и мы- } \\
\text { щелков, измеренное в сагиттальной плоскости. } \\
\text { The degree of curvature of the diaphysis or the distance between the anterior surface of the diaphysis in the middle of the bone } \\
\text { length and the plane drawn between the posterior surfaces of the head and the condyles, measured in the sagittal plane. }\end{array}$ \\
\hline
\end{tabular}

\section{РЕЗУЛЬТАТЫ ИССЛЕДОВАНИЯ И ИХ ОБСУЖДЕНИЕ}

Изменения картины факторных нагрузок на исследуемые параметры плечевых костей контрлатеральных конечностей человека и их дисперсии прекратились при выделении 3 факторов. Для бедренных костей - при выделении 4 факторов.

При анализе факторной структуры костей независимо от принадлежности кости к поясу конечностей и стороне тела были обнаружены постоянно присутствующие параметры. Их мы приняли в качестве стабильных базовых структурных параметров первого уровня (рисунки 2-3). Параметры, характерные для структурной организации костей, относящихся к одному поясу конечностей - либо плечевой, либо бедренной, мы рассматривали в качестве стабильных базовых структурных параметров второго уровня. Параметры, присутствующие в структуре лишь одной из костей - правой плечевой, левой плечевой, правой бедренной или левой бедренной, мы считали системно нестабильными.
В структурной организации плечевой и бедренной костей человека независимо от принадлежности к поясу конечностей и стороне тела определилась группа стабильных базовых параметров первого уровня, состоящая из вертикального диаметра головки, диаметров шейки, длины кости, ширины дистального эпифиза, сагиттального диаметра медиального гребня блока плечевой кости или медиального мыщелка бедренной кости. Данные параметры участвуют в передаче веса тела на нижележащие отделы конечности и указывают на прохождение механической оси конечностей через медиальные отделы дистального эпифиза костей $[4,8]$. Трансляция веса через диафиз бедренной кости приводит к появлению его изогнутости в сагиттальной плоскости. В связи со снижением опорной роли конечности, для плечевой кости не характерно наличие выраженной изогнутости кпереди. Хотя, ряд исследователей указывают на сагиттальную вытянутость сечения диафиза кости [1]. В любом случае, параметры плечевых и бедренных костей, обеспечивающие трансляцию веса, будут являться стабильными базовыми структурообразующими параметрами первого уровня (рис. 2, 3). 
Обозначение структур дистального эпифиза плечевых и бедренных костей человека The osteometric parameters of the distal epiphysis structures of human humerus and femur

\begin{tabular}{|c|c|}
\hline $\begin{array}{l}\text { Homep } \\
\text { Number }\end{array}$ & $\begin{array}{c}\text { Обозначение } \\
\text { The osteometric parameters }\end{array}$ \\
\hline 20 & $\begin{array}{l}\text { Ширина дистального эпифиза - наибольшее расстояние между надмыщелками. } \\
\text { The width of the distal epiphysis is the greatest distance between the epicondyles. }\end{array}$ \\
\hline 21 & $\begin{array}{l}\text { Ширина локтевой ямки плечевой кости / Ширина межмыщелковой ямки бедренной кости - } \\
\text { внутреннее расстояние между краями ямок. } \\
\text { The width of the ulnar fossa of humerus / The width of the intercondylar fossa of femur, it is the internal distance between the } \\
\text { edges of the pits. }\end{array}$ \\
\hline 22 & $\begin{array}{l}\text { Высота локтевой ямки. } \\
\text { The length of the antecubital fossa. }\end{array}$ \\
\hline 23 & $\begin{array}{l}\text { Ширина лучевой ямки. } \\
\text { The width of the radial fossa. }\end{array}$ \\
\hline 24 & $\begin{array}{l}\text { Ширина венечной ямки. } \\
\text { The width of the coronal fossa. }\end{array}$ \\
\hline 25 & $\begin{array}{l}\text { Ширина суставной поверхности для надколенника. } \\
\text { The width of the articular surface for the patella. }\end{array}$ \\
\hline 26 & $\begin{array}{l}\text { Сагиттальный диаметр медиального гребня блока плечевой кости или сагиттальный размер } \\
\text { медиального мыщелка бедренной кости. } \\
\text { The sagittal diameter of the medial crest of the humerus trochlea or the sagittal size of the medial condyle of femur. }\end{array}$ \\
\hline 27 & $\begin{array}{l}\text { Сагиттальный диаметр латерального гребня блока плечевой кости или сагиттальный размер } \\
\text { латерального мыщелка бедренной кости. } \\
\text { The sagittal diameter of the lateral crest of the humerus trochlea or the sagittal size of the lateral condyle of femur. }\end{array}$ \\
\hline 28 & $\begin{array}{l}\text { Вертикальный диаметр медиального гребня блока плечевой кости. } \\
\text { The vertical diameter of the medial crest of the humerus trochlea. }\end{array}$ \\
\hline 29 & $\begin{array}{l}\text { Вертикальный диаметр латерального гребня блока плечевой кости. } \\
\text { The vertical diameter of the lateral crest of the humerus trochlea. }\end{array}$ \\
\hline 30 & $\begin{array}{l}\text { Ширина медиальной части суставной поверхности блока для плечевых костей. Ширина сустав- } \\
\text { ной поверхности медиального мыщелка для бедренных костей. } \\
\text { The width of the medial part of the articular surface of the humerus trochlea. The width of the articular surface of the medial } \\
\text { condyle for femur. }\end{array}$ \\
\hline 31 & $\begin{array}{l}\text { Ширина латеральной части суставной поверхности блока для плечевых костей. Ширина су- } \\
\text { ставной поверхности латерального мыщелка для бедренных костей. } \\
\text { The width of the lateral part of the articular surface of the humerus trochlea. The width of the articular surface of the lateral } \\
\text { condyle for femur. }\end{array}$ \\
\hline 32 & $\begin{array}{l}\text { Ширина суставной поверхности головочки, ограниченная латеральным гребнем, измеренная } \\
\text { на середине высоты передней поверхности мыщелка. } \\
\text { The width of the articular surface of the head limited by the lateral crest, measured in the middle of the height of the anterior } \\
\text { surface of the condyle. }\end{array}$ \\
\hline 33 & $\begin{array}{l}\text { Вертикальный диаметр головочки - измеряется между нижней и верхней точками суставной } \\
\text { поверхности головочки при виде спереди. } \\
\text { The vertical diameter of the head is measured between the lower and upper points of the articular surface of the head when } \\
\text { viewed from the front. }\end{array}$ \\
\hline 34 & $\begin{array}{l}\text { Ширина медиального надмыщелка - расстояние, измеренное горизонтально от максимально } \\
\text { выступающей точки надмыщелка до края суставной поверхности. } \\
\text { The width of the medial epicondyle is the distance measured horizontally from the maximally protruding point of the epicon- } \\
\text { dyle to the edge of the articular surface. }\end{array}$ \\
\hline 35 & $\begin{array}{l}\text { Ширина латерального надмыщелка - расстояние, измеренное горизонтально от максимально } \\
\text { выступающей точки надмыщелка до края суставной поверхности. } \\
\text { The width of the lateral epicondyle is the distance measured horizontally from the maximally protruding point of the epicon- } \\
\text { dyle to the edge of the articular surface. }\end{array}$ \\
\hline
\end{tabular}

Примечание: Серым цветом обозначены ячейки структур, характерных только для одной из костей.

Note: The gray color indicates the structures that are specific to only one of the bones. 


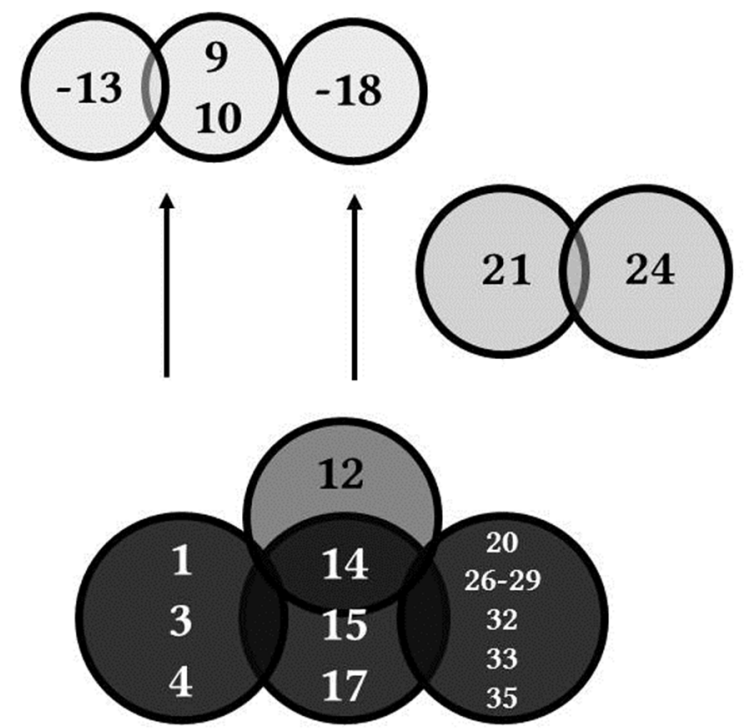

Правая плечевая кость Right humerus

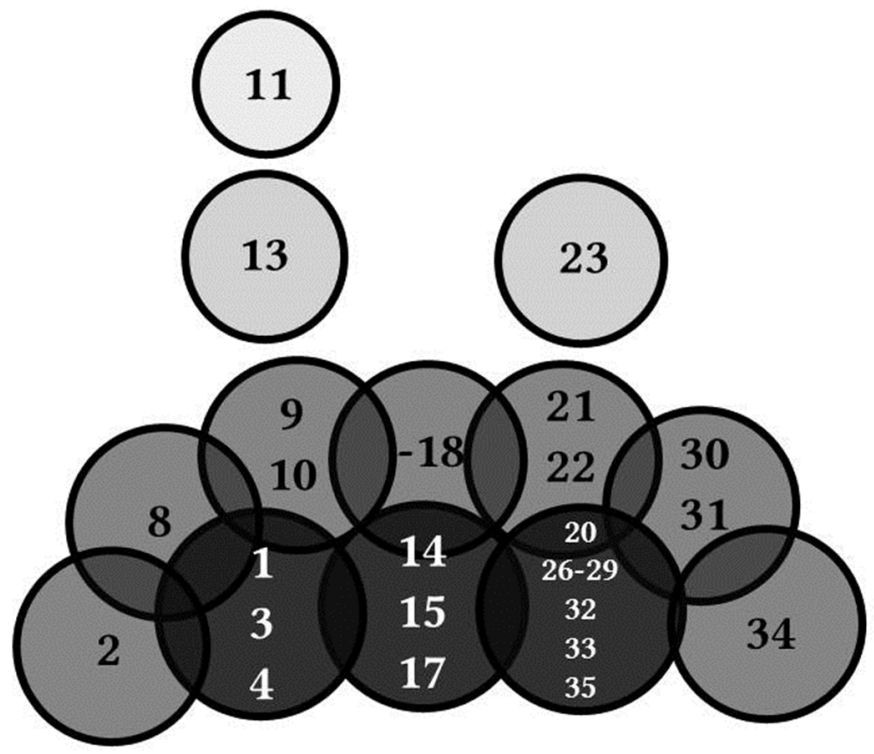

Левая плечевая кость Left humerus

Рис. 2. Структурная организация плечевых костей человека.

Примечание: На схеме представлены параметры, имеющие факторные нагрузки с силой $|0,7-1,0|$ при $\mathrm{p} \geq 0,05$. Отрицательным знаком обозначено обратное влияние. Номера параметров соответствуют данным таблиц 1-3.

Fig. 2. Structural organization of human humerus.

Note: the diagram shows the parameters having factor loads with force $|0.7-1.0|$ at $\mathrm{p} \geq 0.05$. A negative sign indicates the opposite effect. The parameter numbers correspond to the data in tables 1-3.
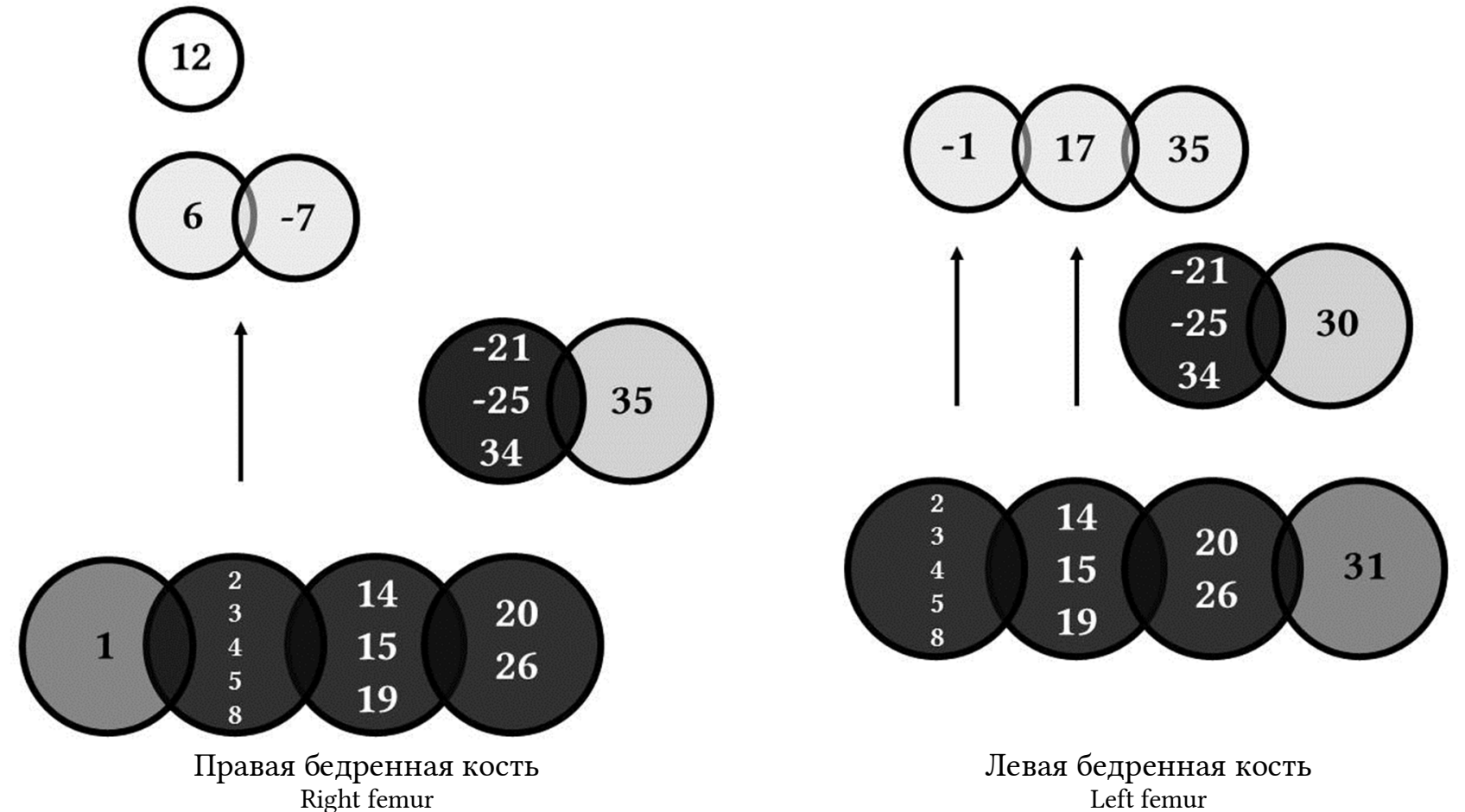

Левая бедренная кость Left femur

Рис. 3. Структурная организация бедренных костей человека.

Примечание: На схеме представлены параметры, имеющие факторные нагрузки с силой $|0,7-1,0|$ при $\mathrm{p} \geq 0,05$. Отрицательным знаком обозначено обратное влияние. Номера параметров соответствуют данным таблиц 1-3.

Fig. 3. The structural organization of the human femur.

Note: the diagram shows the parameters having factor loads with force $|0.7-1.0|$ at $\mathrm{p} \geq 0.05$. A negative sign indicates the opposite effect. The parameter numbers correspond to the data in tables 1-3. 
Особенностью структурной организации плечевой кости независимо от принадлежности к стороне тела явилось выделение ширины проксимального эпифиза в качестве базового структурного параметра первого уровня. Данный параметр, измеренный от медиального края суставной головки до латерального края большого бугорка, отражает функционирование m. pectoralis major и $\mathrm{m}$. supraspinatus, m. infraspinatus, m. teres minor, которые обеспечивают отведение - приведение и вращение руки в плечевом суставе вокруг вертикальной оси.

Особенности структурной организации бедренной кости проявились наличием факторных нагрузок на сагиттальный диаметр головки и межвертельное расстояние. Данные параметры мы отнесли к стабильным базовым структурообразующим параметрам бедренной кости первого уровня. Сферичность головки, подтвержденная факторными нагрузками на вертикальный и сагиттальный диаметры головки бедренной кости, наряду с факторными нагрузками на межвертельное расстояние (место фиксации мышц, обеспечивающих вертикальное положение туловища и вращательные движения в тазобедренном суставе) свидетельствует об увеличении влияния прямохождения при формировании структуры бедренной кости человека.

На уровне дистальных эпифизов структурная организация костей показывает отличия, связанные с функциональной дифференциацией конечностей. В структурной организации плечевой кости человека базовую роль играют параметры, обеспечивающие максимальную амплитуду сгибательно-разгибательных и ротационных движений в локтевом суставе. Это диаметры латерального гребня блока, размеры головочки блока плечевой кости и ширина латерального надмыщелка. Последний является местом прикрепления $\mathrm{m}$. brachioradialis, $\mathrm{mm}$. extensor carpi radialis longus et brevis, mm. extensor digitorum et digiti minimi, m. extensor carpi ulnaris и m. supinator - мышц, обеспечивающих разгибание в нижележащих суставах, супинацию предплечья и кисти в физиологическое состояние $[7,9]$. Перечисленные параметры также входят в группу стабильных структурных параметров плечевой кости первого уровня.

Активные сгибательно-разгибательные движения при ходьбе наряду с поддержанием вертикального положения тела на уровне коленного сустава невозможно без симметричного участия обоих мыщелков бедренной кости, что подтверждается факторными нагрузками на латеральный мыщелок бедра. Ранее нами было обнаружено, что механизмы «замыкания» локтевого и коленного суставов [3], как стабилиза- торы вертикальной оси конечностей животных, у человека на уровне плечевой кости достаточно сильно редуцировались. Это проявилось отсутствием стабильных базовых структурообразующих параметров в организации плечевой кости. Механизм «замыкания» коленного сустава у человека остался сохранным. Стабильными базовыми структурными параметрами бедренной кости второго уровня явились ширина суставной поверхности надколенника и ширина межмыщелковой ямки, показывающие отрицательные факторные нагрузки. Кроме этого, прямохождение невозможно без активного участия приводящих мышц. Нижняя порция m. adductor magnus прикрепляется на медиальном надмыщелке бедра, образуя приводящий бугорок tuberculum adductorium. M. adductor magnus проходит позади оси тазобедренного сустава, она является его разгибателем, одновременно приводя и супинируя конечность. С точки зрения биомеханики нижняя конечность человека представляет собой многозвеньевой механизм, основу функционирования которого составляет чередующееся расположение мышцантагонистов. И если вверху к медиальному надмыщелку прикрепляется разгибатель тазобедренного сустава, то к его нижней поверхности прикрепляется m. gastrocnemius, сгибатель коленного сустава, препятствующая запрокидыванию тела кпереди [4]. Таким образом, медиальный надмыщелок бедренной кости вместе с шириной надколенниковой поверхности и межмыщелковой ямки бедренной кости являются стабильными базовыми параметрами, обеспечивающими вертикальное положение тела при стоянии.

Возникающие в ходе эволюции человека морфофункциональные отличия конечностей проявляются наличием нестабильных параметров в структурной организации плечевой и бедренной костей. Появление таких параметров указывает не только на асимметричность структурной организации сравниваемых костей, характерную для обоих поясов конечностей, но и на наличие вертикальной дифференциации их эпифизов. Исходя из результатов исследования, организация бедренной кости более структурна. Нестабильных параметров проксимального эпифиза правой бедренной кости выделено 4, дистального эпифиза - 1 ; в структурной организации проксимального эпифиза левой бедренной кости выделен 1 , дистального эпифиза - 3 . При этом нестабильными параметрами проксимального эпифиза правой бедренной кости оказались ширина проксимального эпифиза, верхняя и нижняя длины шейки и угол антеверсии шейки и головки бедра. Эти параметры обеспечивают передачу веса тела во фронтальной 
плоскости и соответствуют прохождению механической оси конечности через головку тазобедренного сустава $[5,6,8]$. Данная особенность структурной организации проксимального эпифиза правой бедренной кости, на наш взгляд, указывает на большее участие правой бедренной кости в реализации опорной функции. Нестабильными параметрами дистального эпифиза левой бедренной кости явились ширина латерального и медиального мыщелка и ширина латерального надмыщелка. Функциональная роль выделенных структур заключается в передаче веса через коленный сустав. Таким образом, в структурной организации бедренной кости максимально ярко проявилось явление вертикального разделения эпифизов контрлатеральных костей по выполняемым функциям.

Структурная организация плечевых костей резко асимметрична, что связано с явлениями функционального доминирования одной из рук. Правая плечевая кость отличается меньшим числом коррелированных нестабильных параметров: в структуре проксимального эпифиза выделено 3 параметра, в структуре дистального - 2. При этом в структуре эпифизов левой плечевой кости нестабильных параметров выделено в два раза больше. При рассмотрении функциональной роли выделенных параметров, обращает на себя внимание факт присутствия на разных уровнях структурной организации обеих плечевых костей параметров, свидетельствующих о различной двигательной активности конечности в плечевом суставе. Это размеры межбугорковой борозды, содержащие длинную головку бицепса, угол хрящевого края головки с диафизом, угол наклона диафиза. Факторные нагрузки на ширину и глубину межбугорковой борозды свидетельствуют о асимметричности выполнения сгибания и разгибания в плечевом суставе. Амплитуда движений правого плечевого сустава в сагиттальной плоскости будет лимитироваться величиной углов, характеризующих стереометрию головки плечевой кости и влияющих на биомеханику двуглавой мышцы плеча. В структуре дистального эпифиза правой кости присутствуют параметры, определяющие объем вращательных движений предплечья вокруг лучевой кости. Факторные нагрузки на межбугорковое расстояние, определяемые в структуре левой плечевой кости, указывают на большую вращательную активность в плечевом суставе, присущую левой плечевой кости. В структуре дистального эпифиза левой плечевой кости большую роль играют параметры, обеспечивающие передачу силовых нагрузок по оси конечности: высота локтевой ямки, ширина суставных поверхностей блока, ширина медиального надмыщелка.
Вывод: независимо от принадлежности к поясам конечностей и стороне тела, основу структурной организации плечевой и бедренной костей человека формируют анатомические образования, участвующие в трансляции силовых нагрузок по осям конечностей. Морфофункциональная асимметрия контрлатеральных плечевых и бедренных костей человека, а также различия функциональной специализации их эпифизов определяются количеством уровней системной организации и спектром факторных нагрузок.

\section{КОНФЛИКТ ИНТЕРЕСОВ}

Авторы декларируют отсутствие явных и потенциальных конфликтов интересов, связанных с публикацией настоящей статьи.

\section{ИСТОЧНИКИ ФИНАНСИРОВАНИЯ}

Авторы заявляют об отсутствии финансирования.

\section{СООТВЕТСТВИЕ ПРИНЦИПАМ ЭТИКИ}

Исследование костного материала проведено с соблюдением всех этических норм и правил с разрешения РЭК КГМУ, протокол № 5 от 30.06.2018 г.

\section{ЛИТЕРАТУРA/REFERENCES}

1. Николенко В.Н., Фомичева О.А. Индивидуальная и типовая анатомическая изменчивость макромикроскопического строения плечевой кости. Саратовский научно-медищинский журнал. 2007; 3: 29-31. [Nikolenko V.N., Fomicheva O.A. Individual and typical anatomical variability of the macromicroscopical structure of humeral bone. Saratov Journal of Medical Scientific Research. 2007; 3: 29-31. (in Russ.)]

2. Яшина И.Н., Иванов Д.А., Иванов А.В., Колесник А.И., Самаха А.А., авторы; Яшина И.Н., Иванов Д.А., Иванов А.В., Колесник А.И., Самаха А.А., патентообладатели. Устройство для антропометрических измерений длинных трубчаmblx костей. Российская Федерация патент RU 2245101. 27 января 2005 г. [Yashina I.N., Ivanov D.A., Ivanov A.V., Kolesnik A.I., Samakha A.A., inventors; Yashina I.N., Ivanov D.A., Ivanov A.V., Kolesnik A.I., Samakha A.A., assignees. Device for anthropometric measurements of long tubular bones. Russian Federation patent RU 2245101. 2005 Jan 27 (in Russ.)].

3. Яшина И.Н., Клочкова С.В., Иванов А.В., Вагапова В.Ш. Адаптационная гармоничность в строении проксимального эпифиза плечевых костей человека и некоторых животных. Медицинский вестник Башкортостана. 2018; 13(6-78): 51-54. [Yashina I.N., Klochkova S.V., Ivanov A.V., Vagapova V.Sh. Adaptive harmony in the structure of the proximal epiphysis of the humerus in humans and some animals. Meditsinskiy vestnik Bashkortostana. 2018; 13(6(78)): 51-54. (in Russ.)] 
4. Cronin N.J., Avela J., Finni T., Peltonen J. Differences in contractile behaviour between the soleus and medial gastrocnemius muscles during human walking. f Exp Biol. 2013; 216(Pt 5): 909-914. DOI: $10.1242 /$ jeb.078196.

5. Fong D.T., Chan Y.Y. The Use of Wearable Inertial Motion Sensors in Human Lower Limb Biomechanics Studies: A Systematic Review. Sensors (Basel). 2010; 10(12): 11556-11565. DOI: 10.3390/s101211556.

6. Foucher K.C. Gait abnormalities before and after total hip arthroplasty differ in men and women. 7 Biomech. 2016; 49(14): 3582-3586.

DOI: $10.1016 /$ j.jbiomech.2016.09.003

7. Güleçyüz M.F., Pietschmann M.F., Michalski S., Eberhard F.M., Crispin A., Schröder C., Mittermüller M.J., Müller P.E. Reference Values of Flexion and Supination in the Elbow Joint of a Cohort without Shoulder
Pathologies. Biomed Res Int. 2017; 2017: 1654796. DOI: $10.1155 / 2017 / 1654796$.

8. Mu X., Chen J., Du F. Biomechanics analysis of human lower limb during walking for exoskeleton design. Journal of Vibroengineering. 2017; 19(7): 5527553. DOI: $10.21595 /$ jve.2017.18459

9. Roach N., Lieberman D.E., Gill Iii T. J., Palmer W.E. The effect of humeral torsion on rotational range of motion in the shoulder and throwing performance. f Anat. 2012; 220(3): 293-301. DOI: 10.1111/j.14697580.2011.01464.x.

10. Samaha A.A., Ivanov A.V., Haddad J.J., Kolesnik A.I., Baydoun S., Arabi M.R., Yashina I.N., Samaha R.A., Ivanov D.A. Asymmetry and structural system analysis of the proximal femur meta-epiphysis: osteoarticular anatomical pathology. F Orthop Surg Res. 2008; 3: 11. DOI: 10.1186/1749-799X-3-11

Для цитирования: Яшина И.Н., Иванов А.В., Клочкова С.В. К вопросу гомологии в структурной организации костей проксимальных сегментов конечностей человека. Курский научно-практический вестник «Человек и его здоровье». 2019;(1):83-92. DOI: $10.21626 /$ vestnik/2019-1/10.

\title{
TO THE QUESTION OF HOMOLOGY IN THE STRUCTURAL ORGANIZATION OF BONES OF HUMAN LIMB PROXIMAL SEGMENTS
}

\author{
(c) Yashina I.N. ${ }^{1}$, Ivanov A.V. ${ }^{1}$, Klochkova S.V. ${ }^{2}$ \\ ${ }^{1}$ Kursk State Medical University (KSMU) \\ 3, K. Marx str., Kursk, Kursk region, 305041, Russian Federation \\ ${ }^{2}$ I.M. Sechenov First Moscow State Medical University (Sechenov University) \\ 11, building 10, Mokhovaya str, Moscow, 125009, Russian Federation
}

\begin{abstract}
Objective. The main aim of the research is to discover regularities and specific features of systemic structural organization of the human humeral and femoral bones according to the functions of extremities and their belonging to the side of the
\end{abstract} body.

Materials and methods. By the classic osteometry with some authors' modifications 35 anatomical structures on 308 of humerus and femur have been measured. All the bones had no pathological symptoms, with complete synostosis of epiphyses. To access the somatotype effect on the dimensions of human bone structures all the values obtained were normalized. As a unit for measurement normalization the transverse diameter of the shaft in the middle of the bone length was chosen. The values obtained were processed by the methods of factor analysis Maximum Maximum Likelihood Factor with rotation Equamax normalized, and four groups were generated according to the limb girdle and the side of the body.

Results. The asymmetry of the structural organization of bones and vertical differentiation of their epiphyses are determined by the presence of unstable parameters. The asymmetry of the structural organization of the femur is more pronounced. Unstable parameters were found in the proximal epiphysis of the right femur - 4, in the distal epiphysis - 1 ; in the proximal epiphysis of the left femur - 1, in the distal epiphysis - 3. Unstable parameters of the proximal epiphysis of the right humerus made up 3, distal epiphysis - 2; in the structural organization of the epiphysis of the left humerus 6 unstable parameters were identified.

Conclusion. The basis of the structural organization of the bone proximal segments of the human limbs regardless of belonging to the extremity or the side of the body is formed by anatomical objects which are responsible for conveying the power loads along the axis of the limb. Functional differentiation of human limbs is shown in the structural organization of both bones by asymmetric vertical differentiation of their epiphysis.

Keywords: humerus; femur; structural organization; factor analysis.

Yashina Irina N. - PhD in Medicine, Associate Professor of Human Anatomy Department, KSMU, Kursk, Russian Federation. ORCID iD: 0000-0001-6235-2309. E-mail: bik2709@rambler.ru (correspondence author)

Ivanov Alexander V. - DM, Professor, Head of the Department of Histology, Cytology and Embryology, KSMU, Kursk, Russian Federation. ORCID iD: 0000-0002-2412-0475. E-mail: anatomy@mail.ru

Klochkova Svetlana V. - DM, Professor of the Department of Human Anatomy, Sechenov University, Moscow, Russian Federation. ORCID iD: 0000-0003-2041-7607. E-mail: swetlana.chava@yandex.ru 


\section{CONFLICT OF INTEREST}

The authors declare the absence of obvious and potential conflicts of interest related to the publication of this article.

\section{SOURCE OF FINANCING}

The authors state that there is no funding for the study.

\section{CONFORMITY WITH THE PRINCIPLES OF ETHICS}

The study of bone material was carried out in compliance with all ethical norms and rules and was approved by the Regional Ethical Committee under KSMU (Protocol No. 5 of 30.06.2018).

Received 05.12.2018 Accepted 21.03.2019

For citation: Yashina I.N., Ivanov A.V., Klochkova S.V. To the question of homology in the structural organization of bones of human limb proximal segments. Kurskiy nauchno-prakticheskiy vestnik "Chelovek $i$ ego zdorov'ye" = Kursk Scientific and Practical Bulletin "Man and His Health". 2019;(1):83-92. DOI: 10.21626/vestnik/2019-1/10. 